\title{
Pupa Çayı Havzası’nın (Isparta) Besin Elementleri Yükünün Belirlenmesi*
}

\section{Ayça ASLANTÜRK**, Osman ÇETINKAYA}

\author{
Süleyman Demirel Üniversitesi, Eğirdir Su Ürünleri Fakültesi, Su Ürünleri Temel Bilimleri \\ Bölümü, Isparta.
}

Geliş : : 17.05.2016

Kabul : 29.09.2016

Araştırma Makalesi / Research Article

**Sorumlu yazar: aycaakar@windowslive.com

E-Dergi ISSN: $1308-7517$

Özet

Güney-Batı Anadolu'da Göller Bölgesinde yer alan Pupa Çayı havzası sularını Eğirdir Gölü’ne boşaltmaktadır. Bu çalışma Pupa Çayı ve Eğirdir Gölü' nün kirlenmesinde etken olan havza besin elementleri yükünün ortaya konulması ve besin elementleri kirliliği kontrolü için havzada alınabilecek önlemlerin belirlenmesi amacıyla yapılmıştır. Çalışmada Ağustos 2011-Mayıs 2012 arasında havzada seçilen 7 noktada mevsimsel olarak alınan örneklerle havza yüzey sularının besin elementleri konsantrasyonları belirlenmiş, incelemeler yapılmış ve gübre kullanım verileri toplanmıştır. Havzanın Eğirdir Gölü'ne yüklediği $\mathrm{NO}_{3}-\mathrm{N}$ $205,004 \mathrm{~kg} / \mathrm{y} 11, \mathrm{NH}_{4}-\mathrm{N} 184,870 \mathrm{~kg} / \mathrm{y} 11, \mathrm{PO}_{4}-\mathrm{P} 560,624 \mathrm{~kg} / \mathrm{y} 1 \mathrm{l}$ olarak hesaplanmıştır. Kullanılan kimyasal ve organik (hayvansal) gübreler havza besin elementi yükü üzerinde etkili olup, gübrelerin havzada su kirliliği oluşturma potansiyeline sahip olduğu görülmektedir. Pupa çayı, kolları ve sulama kanalları yerleşim yerlerinden arıtılmadan yüzey suyuna verilen evsel atıklar ve tarımsal kirleticilerin etkisi altındadır. Havzadan yüzey ve yer altı sularına geçen besin elementi yükünün azaltılması için kentsel atık su arıtımı, iyi tarım uygulamaları, daha az ve doğru gübre kullanımı konularında önlemler alınmalıdır.

Anahtar kelimeler: Nitrat, Amonyum, Ortofosfat, Havza, Ötrofikasyon, Su kirliliği

\section{Estimation of NutrientsLoad of Pupa RiverBasin(Isparta, Turkey)}

\begin{abstract}
The Pupa river basin, located in Lakes District of Turkey, south-east Anatolia. The basin inflows it's waters to LakeEğirdir. The purpose of this study was to estimate nutrients loading rates to Lake Eğirdir that is a pollution causative factor for the lake and to suggest pollution control measures that can be applied for lake Eğirdir on the basin level, based to the investigations and estimations. Nutrient concentrations of the Pupa River'sbasin were determined through seasonal samples obtained at 7 sampling points between August 2011 and May 2012. In the same time investigations were made and fertilizers and manure usage data in the basin were collected. The nitrate nitrogen, ammonia nitrogen, orthophosphate loads per year for the lake Eğirdir coming from the basin were estimated as $205.004 \mathrm{~kg} ; 184.870 \mathrm{~kg} ; 560.624 \mathrm{~kg}$, respectively. It can be seen that artificial fertilizers and animal manures used in the basin are efficient on nutrient load of the basin and it was established that these fertilizers potentially caused water pollution in the area. On the investigations it can be clearly seen that the Pupa River'sbasin is influenced by pollutants as municipal wastes which are passed into the surface water without any treatment or purification, and agricultural wastes and fertilizers. There is an urgent need for taking precautions for minimizing the nutrient load coming from the basin into surface and groundwater and measures should be taken in municipal waste water treatment and in good agricultural practices such as less and on time fertilizer usage.
\end{abstract}

Keywords: Nitrate, Ammonium, Orthophosphate, Basin, Eutrophication, Water pollution

*Bu çalışma 2819-YL-11 numarasıyla SDÜ-BAP tarafından desteklenen yüksek lisans tezinden özetlenmiş̧ir. V. Ulusal Limnoloji Sempozyumu'nda sözlü bildiri olarak sunulmuştur. 


\section{GİRIŞ}

Hayatın doğuş yeri olan su, canlı yaşamının sürdürebilmesi için gerekli en temel kaynaklardan biridir. Hızlı nüfus artışı, endüstriyel ve tarımsal faaliyetler gibi etkenler suya olan gereksinimi artırmakta bu durumda da mevcut su kaynaklarının daha dikkatli kullanılması ve kirlenmeye karşı gerekli tedbirlerin bir an önce alınmasını gerektirmektedir (Demer, 2008).

$\mathrm{Su}$ kaynaklarının kirlenmesinde önemli role sahip kirletici gruplarından biri besin elementleridir. Besin elementlerinden $\mathrm{N}$ ve $\mathrm{P}$ ortamda doğal olarak düşük konsantrasyonlarda bulunurken asıl olarak insan faaliyetleri (baraj inşası, sulak alanların drenajı ve akış yönü ve miktarının değiştirilmesi, kanalizasyon, tarım arazilerinden gelen kimyasallar gibi) sonucu ortaya çıkar(UNEP/WHO, 1996; Lijeström, 2007).

Türkiye'nin önemli tatlı su göllerinden biri olan Eğirdir Gölü; içme ve kullanma suyu, sulama, balıkçılık, rekreasyon ve su sporları gibi çok amaçlı olarak kullanılmaktadır. Göle katılan akarsuların gölün kirlenmesinde etkili olduğu sıkça dile getirilmektedir (Mutlutürk vd., 1991; Şener vd., 2010). Eğirdir Gölü’ne dökülen akarsulardan biri de Pupa Çayıdır. Pupa çayı havzasının gerek kentsel atıklar gerekse tarım alanları itibariyle azot ve fosfor verme potansiyeli net olarak bilinmemektedir.

$\mathrm{Bu}$ çalışma ile Pupa Çayı'nın besin elementi durumunu belirlemek, kirlenme kaynakları konusunda bir bakış açısı sağlamak, Eğirdir Gölü’nün kirlenmesi ile ilgili kaygılar konusunda bilimsel veriler ortaya koymak, havzadan Eğiridir gölüne besin elementi yüklemesini nicelik olarak tahmin etmek amaçlanmıştır. Ayrıca, havzadan kaynaklanan $\mathrm{N}$ ve $\mathrm{P}$ şekilleri ile bu şekillere dayalı olarak azot ve fosforun kökenleri belirlenmeye çalışılmıştır.

\section{MATERYAL ve YÖNTEM}

\section{Çalışma alanı}

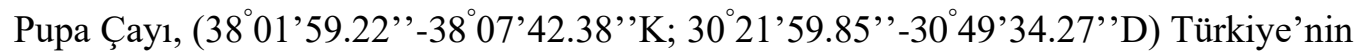
Göller Bölgesi'nde ve Eğirdir Gölü'nün batısında olup gölü besleyen en önemli akarsulardan biridir. Isparta Uluborlu ilçesi batısından doğmakta ve Senirkent'in içinden geçerek Eğirdir Gölü'ne dökülmektedir. Pupa Çayı yaklaşık 45 km uzunluğa sahiptir. Havza alanı yaklaşık 753 km², dir (Şekil 1) (Tay, 2005).

Havzada; Senirkent ilçesi merkezde 5747 kişi ve belde ve köylerde 6845 kişi olmak üzere toplamda 12292 nüfus; Uluborlu ilçesi ise merkezde 6060 kişi ve köylerde 1105 kişi olmak üzere toplam 7165 nüfus, havzanın tümünde toplam nüfus 19457 yaşamaktadır (TÜİK, 2014).

Havzadan Pupa Çayı, sulama kanalları artık suyu ve Delipınar Kaynağı ile Eğirdir Gölü'ne boşalım olmaktadır. Pupa çayı üzerinde Senirkent köprüsünde 1974-2000 yılları arasında DSİ tarafından yapılan ölçümlerde ortalama yüzeysel akış miktarı (debi) 12,84 x $10^{6} \mathrm{~m}^{3} /$ yıl olarak bulunmuştur. Ancak ölçüm yapılan nokta havzanın ortasında bulunduğundan ve havza drenaj sistemi de göz önünde tutularak toplam yüzeysel akış yolu ile boşalım bu değerin iki katı olan $25,6810^{6} \mathrm{~m}^{3} / \mathrm{y} 1 \mathrm{l}$ olarak kabul edilmiştir (Seyman, 2005). 


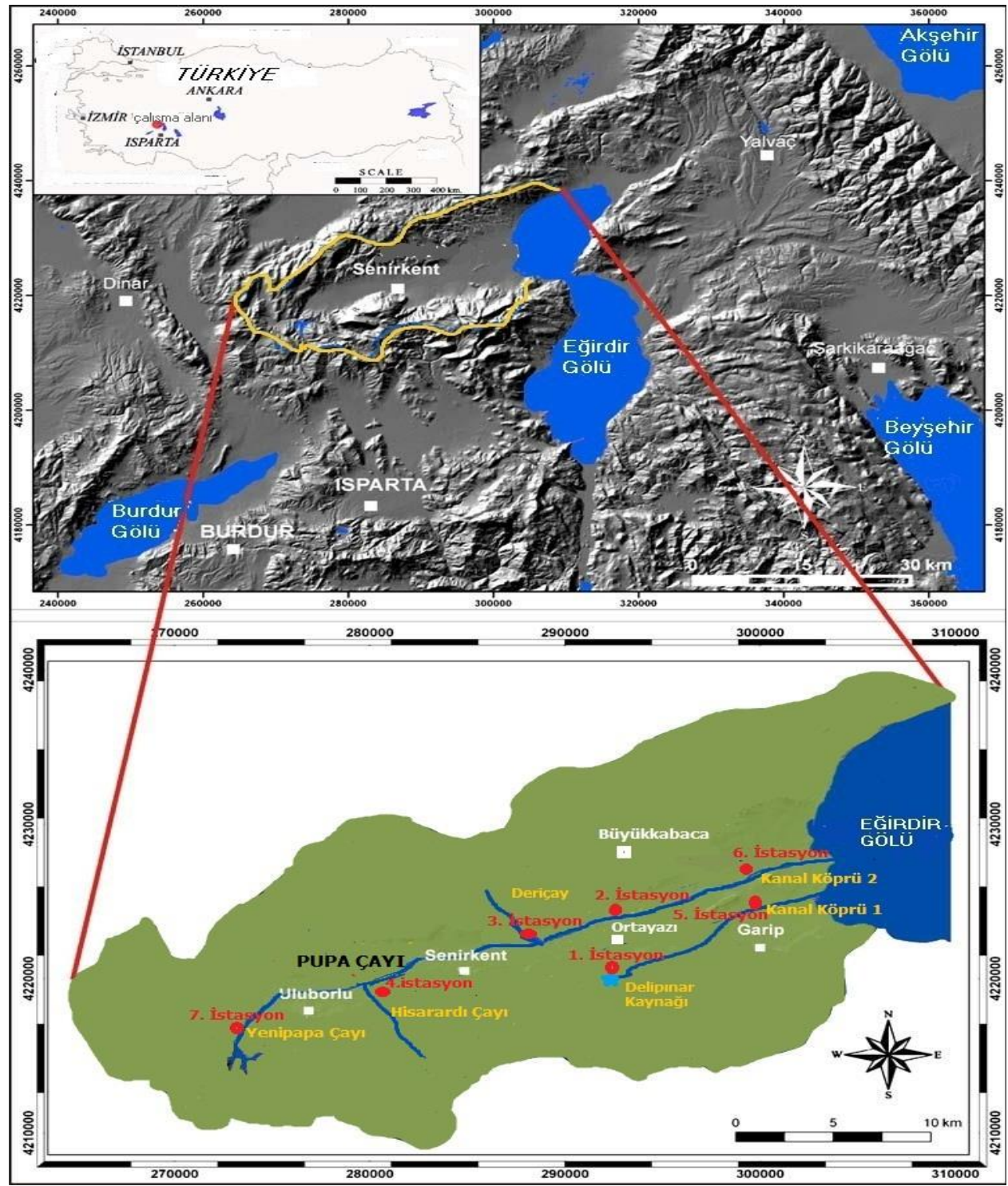

Şekil 1. Çalışma alanı ve istasyonlar (Şener 2009'dan dönüştürülmüştür.)

\section{Su Örneklerinin Alınması, Saklanması ve Çözümlemeleri}

Senirkent-Yalvaç D320 karayolu güzergahında Pupa Çayı üzerinde 5; havzadaki diğer su kaynakları üzerinde 2 istasyon belirlenmiş, koordinatları GPS yardımıyla kaydedilmiştir. Su örnekleri Ağustos 2011- Mayıs 2012 tarihleri arasında mevsimsel olarak alınmıştır.

Su sıcaklığı $\left({ }^{0} \mathrm{C}\right)$, çözünmüş oksijen(mg/l) ve oksijen doygunluğu (\%) WTW Oxi 320 ile; Elektriksel iletkenlik $\left(25^{\circ} \mathrm{C} \mu \mathrm{S} / \mathrm{cm}\right)$ YSI 30 SCT metre ile; pH WTW pH 330i pH metre ile örnek alımı sırasında ölçülmüsstür. Su örneklerinde amonyum azotu $\left(\mathrm{NH}_{4}-\mathrm{N}\right)$, nitrat azotu $\left(\mathrm{NO}_{3}-\mathrm{N}\right)$, ortofosfat fosforu $\left(\mathrm{PO}_{4}-\mathrm{P}\right)$, askıda kat1 madde AKM $(\mathrm{mg} / \mathrm{l})$, bulanıklık (NTU) değerleri laboratuarda ölçülmüştür. $\mathrm{NH}_{4}-\mathrm{N} \quad \mathrm{mg} / \mathrm{l}, \quad \mathrm{NO}_{3}-\mathrm{Nmg} / \mathrm{l}, \quad \mathrm{PO}_{4}-\mathrm{P} \quad \mu \mathrm{g} / \mathrm{l}$ : 
Mercfotometrik test kitleri kullanılarak NOVA 60 spektroquant ile;bulanıklık (NTU); Hatch marka türbiditimetre ile ölçülmüştür.

\section{Besin Elementi Yükünün Belirlenmesi}

Havzanın ortalama yıllık yağış miktarının havza alanı ile çarpılmasından havzanın ortalama yıllık buharlaşma miktarı ile havza alanının çarpımının çıkarılması ile havzanın net su kazancı bulunmuştur (Canik, 1971).

$\mathrm{NSK}=(\mathrm{OY} \times \mathrm{A})-(\mathrm{OB} \times \mathrm{A})$

$\mathbf{O Y}=$ Ort. Yıllık yağış, $\mathbf{O B}=$ Ort. Yıllık buharlaşma, $\mathbf{A}=$ Havzanın alanı

$\mathrm{Su}$ kaynaklarının ortalama besin elementleri konsantrasyonları ile havzanın net su kazancı çarpılarak; havzanın Eğirdir Gölü’ne 1 yılda taşıdığı besin elementleri miktarı bulunmuştur.

$\mathrm{YD}=$ Ort. besin elementi konsantrasyonu $\mathrm{x}$ NSK

Havzadaki su kaynaklarında bulunan besin elementlerinin bir kaynağı da havzada kullanılan hayvansal gübrelerdir. Havzada kullanılan hayvansal gübre miktarının hesaplanmasında havzada bulunan hayvan sayısı baz alınmaktadır. TÜiK'dan alınan 2014 yılı ilçeler bazında hayvan mevcutları ile Yenilenebilir Enerji Genel Müdürlüğü (YEGM)'den alınan verilere göre hayvan başına 1 yılda elde edilebilecek hayvansal gübre miktarları çarpılarak havzada üretilen toplam hayvansal gübre miktarı bulunmuştur.

\section{İstatistik Analizler}

Havzada bulunan besin elementleri konsantrasyonları ile yapılan gübreleme arasındaki iliş̧ki ise Gıda, Tarım ve Hayvancılık Bakanlığı'ndan alınan 2009 yılı Senirkent-Uluborlu ilçelerinde çiftçiye satılan gübre toplamı (ton) verileri ile aylara göre havzada bulunan ortalama besin elementleri konsantrasyonları korelasyon analizi ile incelenmiş, besin elementleri yükleme değerlerinin \% 95'lik güven aralıkları EXCEL paket programı ile hesaplanmıştır.

\section{BULGULAR}

Araştırma süresince çalışma alanında ve laboratuarda belirlenen fizikokimyasal parametreler istasyonlardaki örnek sayıları, en düşük, en yüksek ve ortalama değerleri ve standart hataları Tablol'de, besin elementlerinin aylık değişimleri de Şekil 2-4 'de verilmiştir. 


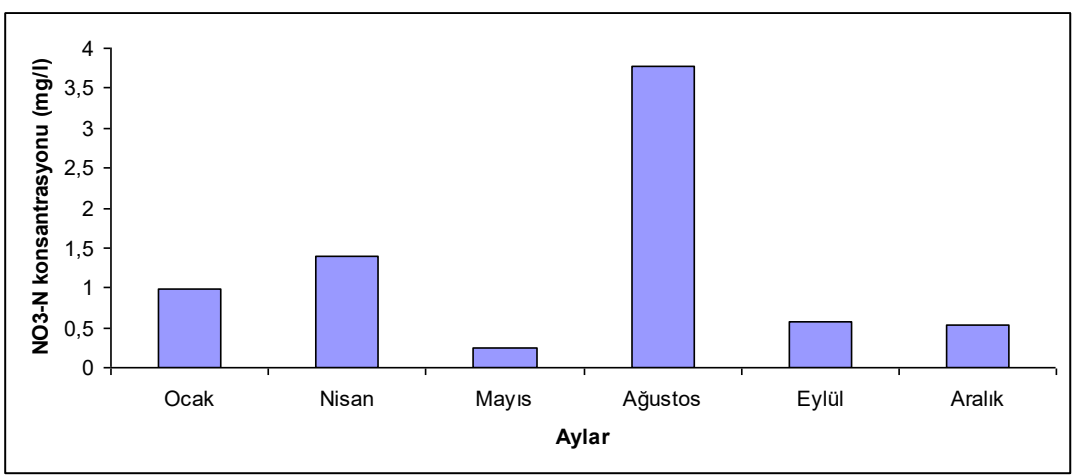

Şekil 2. İstasyonların $\mathrm{NO}_{3}-\mathrm{N}$ konsantrasyonları ortalamasının aylara göre değişimi

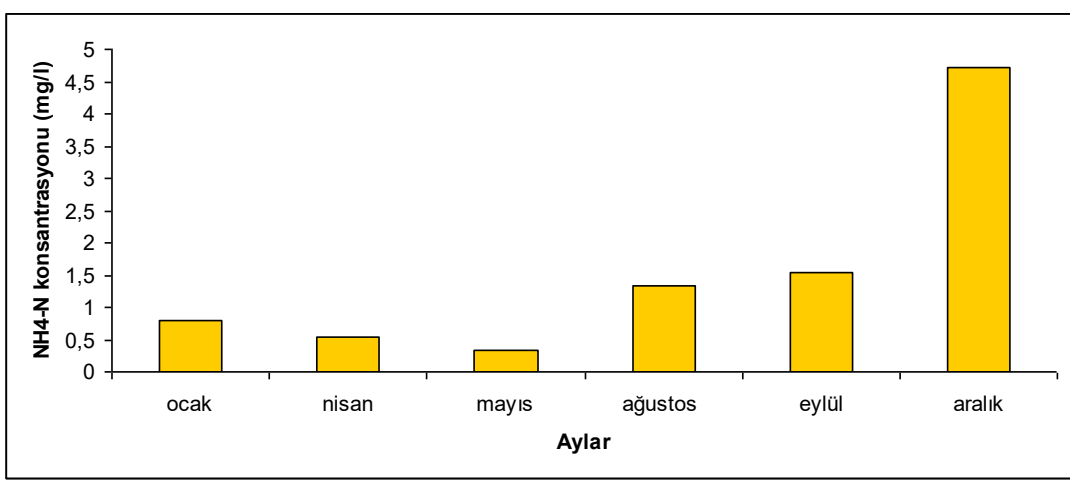

Şekil 3. İstasyonların $\mathrm{NH}_{4}-\mathrm{N}$ konsantrasyonları ortalamasının aylara göre değişimi

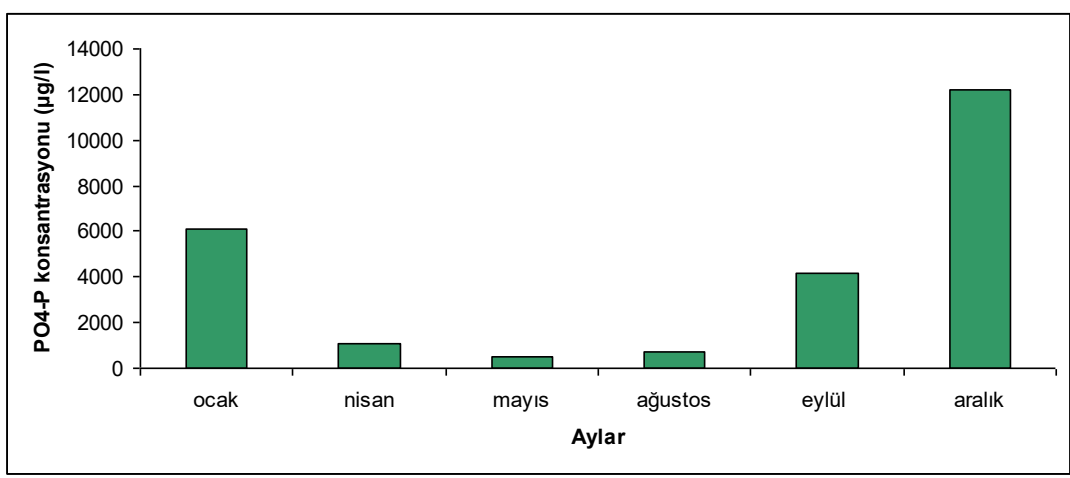

Şekil 4. istasyonların $\mathrm{PO}_{4}-\mathrm{P}$ konsantrasyonları ortalamasının aylara göre değişimi 
Tablo 1. Pupa Çayı Havzasında örnek yerlerinde fizikokimyasal parametrelerinin çalışma süresince belirlenen değerler

\begin{tabular}{|c|c|c|c|c|c|c|c|}
\hline & 1. istasyon & 2. istasyon & 3.istasyon & 4. istasyon & 5. istasyon & 6. istasyon & 7.istasyon \\
\hline Parametreler & $\begin{array}{c}\text { Ort. } \pm \text { SE } \\
\text { Min }- \text { Max }\end{array}$ & $\begin{array}{c}\text { Ort. } \pm \text { SE } \\
\text { Min }- \text { Max }\end{array}$ & $\begin{array}{c}\text { Ort. } \pm \text { SE } \\
\text { Min }- \text { Max }\end{array}$ & $\begin{array}{c}\text { Ort. } \pm \text { SE } \\
\text { Min }- \text { Max }\end{array}$ & $\begin{array}{c}\text { Ort. } \pm \text { SE } \\
\text { Min }- \text { Max }\end{array}$ & $\begin{array}{l}\text { Ort. } \pm \text { SE } \\
\text { Min }- \text { Max }\end{array}$ & $\begin{array}{c}\text { Ort. } \pm \text { SE } \\
\text { Min }- \text { Max }\end{array}$ \\
\hline Su sicaklığ $1\left({ }^{\circ} \mathrm{C}\right)$ & $\begin{array}{c}10,4 \pm 2,26 \\
7,2-17,1(n=4)\end{array}$ & $\begin{array}{c}10,4 \pm 3,44 \\
0,4-20,9(n=6)\end{array}$ & $\begin{array}{c}11,3 \pm 3,567 \\
-1,4-23(n=6)\end{array}$ & $\begin{array}{l}9,3 \pm 2,991 \\
-1-20(n=6)\end{array}$ & $\begin{array}{l}15,4 \pm 3,7 \\
3-24(n=5)\end{array}$ & $\begin{array}{l}13,32 \pm 3,49 \\
1,8-22(n=5)\end{array}$ & $\begin{array}{c}16,55 \pm 0,35 \\
16,2-16,9(n=2)\end{array}$ \\
\hline $\mathrm{pH}$ & $\begin{array}{c}8,3 \pm 0,18 \\
7,85-8,75(n=4)\end{array}$ & $\begin{array}{c}8,9 \pm 0,432 \\
7,72-10,3(n=6)\end{array}$ & $\begin{array}{c}8,913 \pm 0,377 \\
7,7-9,86(n=6)\end{array}$ & $\begin{array}{c}9,08 \pm 0,282 \\
8,37-10,25(n=6)\end{array}$ & $\begin{array}{c}9,4 \pm 0,62 \\
7,55-10,93(n=5)\end{array}$ & $\begin{array}{c}9,39 \pm 0,59 \\
7,48-10,66(n=5)\end{array}$ & $\begin{array}{c}9,8 \pm 0,53 \\
9,27-10,33(n=2)\end{array}$ \\
\hline $\begin{array}{l}\text { Elektriksel iletkenlik } \\
\left(25^{\circ} \mathrm{C}\right)(\mu \mathrm{s} / \mathrm{cm})\end{array}$ & $\begin{array}{c}217,4 \pm 27,2 \\
182,5-298,5(n=4)\end{array}$ & $\begin{array}{c}446,1 \pm 76,387 \\
218,5-690(n=6)\end{array}$ & $\begin{array}{c}341,6 \pm 41,139 \\
216,5-486(n=6)\end{array}$ & $\begin{array}{c}257,9 \pm 30,854 \\
193-366,2(n=6)\end{array}$ & $\begin{array}{c}532 \pm 168,8 \\
314,8-1195(n=5)\end{array}$ & $\begin{array}{c}305,4 \pm 20,6 \\
241,8-368,1(n=5)\end{array}$ & $\begin{array}{c}285,5 \pm 5,86 \\
280-291,7(n=2)\end{array}$ \\
\hline Çözünmüş oksijen (mg/l) & $\begin{array}{c}1,4 \pm 0,26 \\
1,19-2(n=3)\end{array}$ & $\begin{array}{c}2,03 \pm 0,648 \\
0,28-4,21(n=6)\end{array}$ & $\begin{array}{c}4 \pm 0,663 \\
1,7-6,43(n=6)\end{array}$ & $\begin{array}{c}3,8 \pm 1,115 \\
1,45-8,53(n=6)\end{array}$ & $\begin{array}{c}3,3 \pm 0,81 \\
1,15-5,28(n=5)\end{array}$ & $\begin{array}{c}2,7 \pm 0,6 \\
0,18-3,8(n=5)\end{array}$ & $\begin{array}{c}1,07 \pm 0,05 \\
1,02-1,13(n=2)\end{array}$ \\
\hline Oksijen doygunluğu (\%) & $\begin{array}{c}17,2 \pm 2,18 \\
10,7-19,8(n=4)\end{array}$ & $\begin{array}{c}22,4 \pm 8,098 \\
1,8-47,5(n=6)\end{array}$ & $\begin{array}{c}41,6 \pm 7,297 \\
18,5-70,2(n=6)\end{array}$ & $\begin{array}{c}39,2 \pm 11,587 \\
18,2-88,7(n=6)\end{array}$ & $\begin{array}{c}36,8 \pm 9,01 \\
11,6-57,1(n=5)\end{array}$ & $\begin{array}{c}29,3 \pm 7,81 \\
1,5-48(n=5)\end{array}$ & $\begin{array}{c}13,2 \pm 2,7 \\
10,5-15,9(n=2)\end{array}$ \\
\hline Bulanıklık (NTU) & $\begin{array}{c}1,6 \pm 0,34 \\
1,13-2,3(n=3)\end{array}$ & $\begin{array}{l}180,6 \pm 112,6 \\
2,4-612(n=5)\end{array}$ & $\begin{array}{c}257,7 \pm 149,2 \\
11,5-716(n=5)\end{array}$ & $\begin{array}{l}229,7 \pm 137,89 \\
5,3-602(n=5)\end{array}$ & $\begin{array}{l}49,07 \pm 22,8 \\
3,7-96(n=4)\end{array}$ & $\begin{array}{c}103 \pm 40,3 \\
6-196(n=4)\end{array}$ & $\begin{array}{l}24,75 \pm 22,3 \\
2,5-47(n=2)\end{array}$ \\
\hline Askıda katı madde( mg/l) & $\begin{array}{c}1,3 \pm 0,29 \\
0,68-2,1(n=4)\end{array}$ & $\begin{array}{c}15,8 \pm 10,881 \\
0,8-69,1(n=6)\end{array}$ & $\begin{array}{l}29,468 \pm 16,34 \\
0,3-92,8(n=6)\end{array}$ & $\begin{array}{c}21,5 \pm 12,975 \\
0,2-66,8(n=6)\end{array}$ & $\begin{array}{c}2,2 \pm 1,06 \\
0,5-5,1(n=5)\end{array}$ & $\begin{array}{c}59,4 \pm 47,44 \\
2,73-267,2(n=5)\end{array}$ & $\begin{array}{c}124 \pm 2 \\
122-126(n=2)\end{array}$ \\
\hline Nitrat azotu $\left(\mathrm{NO}_{3}-\mathrm{N}\right)(\mathrm{mg} / \mathrm{l})$ & $\begin{array}{c}0,7 \pm 0,24 \\
0,2-1,4(n=4)\end{array}$ & $\begin{array}{c}1,2 \pm 0,434 \\
0,1-3,2(n=6)\end{array}$ & $\begin{array}{c}1,01 \pm 0,321 \\
0,3-2,2(n=6)\end{array}$ & $\begin{array}{c}1,7 \pm 0,988 \\
0,2-6,4(n=6)\end{array}$ & $\begin{array}{c}0,35 \pm 0,134 \\
0,1-0,7(n=5)\end{array}$ & $\begin{array}{c}2,08 \pm 1,05 \\
0,3-6,1(n=5)\end{array}$ & $\begin{array}{c}0,75 \pm 0,45 \\
0,3-1,2(n=2)\end{array}$ \\
\hline Amonyum azotu $\left(\mathrm{NH}_{4}-\mathrm{N}\right)(\mathrm{mg} / \mathrm{l})$ & $\begin{array}{c}0,4 \pm 0,31 \\
0,02-1,28(n=4)\end{array}$ & $\begin{array}{c}2,07 \pm 1,167 \\
0,02-5,8(n=6)\end{array}$ & $\begin{array}{c}3,4 \pm 1,975 \\
0,53-13,2(n=6)\end{array}$ & $\begin{array}{c}0,4 \pm 0,216 \\
0,03-1,4(n=6)\end{array}$ & $\begin{array}{c}0,08 \pm 0,03 \\
0,02-0,2(n=5)\end{array}$ & $\begin{array}{c}0,08 \pm 0,56 \\
0,05-0,3(n=5)\end{array}$ & $\begin{array}{c}0,08 \pm 0,03 \\
0,05-0,12(n=2)\end{array}$ \\
\hline $\begin{array}{l}\text { Orto-Fosfat fosforu } \\
\text { (PO4-P) }(\mu \mathrm{g} / \mathrm{l})\end{array}$ & $\begin{array}{c}6900 \pm 5215 \\
350-19000(n=4)\end{array}$ & $\begin{array}{c}10088,3 \pm 5380 \\
600-27800(n=6)\end{array}$ & $\begin{array}{c}2826,6 \pm 1175 \\
450-8400(n=6)\end{array}$ & $\begin{array}{c}538,3 \pm 314 \\
100-2100(n=6)\end{array}$ & $\begin{array}{c}165 \pm 43,4 \\
40-270(n=5)\end{array}$ & $\begin{array}{c}676 \pm 241,9 \\
150-1500(n=5)\end{array}$ & $\begin{array}{c}215 \pm 145,4 \\
70-360(n=2)\end{array}$ \\
\hline
\end{tabular}




\section{Pupa Çayı Havzası'nın Yıllık Besin Elementleri Yükleme Değerleri}

$\mathrm{NSK}=\left[622 \mathrm{~mm} / \mathrm{y} 1 \mathrm{l} \times 753 \mathrm{~km}^{2}\right]-\left[378,92 \mathrm{~mm} / \mathrm{y} 1 \mathrm{l} \times 753 \mathrm{~km}^{2}\right]=183040 \times 10^{3} \mathrm{~m}^{3} / \mathrm{y} 11$ olarak hesaplanmıştır.

Tablo 2. Havzanın besin elementi yükleme değerleri

\begin{tabular}{ccc}
\hline \hline & $\begin{array}{c}\text { Havzanin ortalama } \\
\text { besin elementi } \\
\text { konsantrasyonu }\end{array}$ & Yükleme kg/y1l \\
\hline Nitrat azotu $(\mathrm{mg} / \mathrm{l})$ & $1,12 \pm 0,23$ & $205,004(162,91-247,1)$ \\
Amonyum azotu $(\mathrm{mg} / \mathrm{l})$ & $1,01 \pm 0,47$ & $184,870(98,84-270,9)$ \\
Ortofosfat fosforu $(\mu \mathrm{g} / \mathrm{l})$ & $3062,85 \pm 1,49$ & $560,624(560,35-560,9)$ \\
\hline \hline
\end{tabular}

Tarımsal faaliyetlerin yoğun olarak yapıldığı bölgelerde besin elementlerinin temel kaynağ1 kullanılan gübrelerdir. Pupa çayı havzasında GTHB Isparta İl Müdürlüğü’nden alınan verilere göre 2009 yılında toplamda 1919,21 ton gübre kullanılmıştır (GTHB 2011). Havzada kullanılan gübreler ile havzanın ortofosfat fosforu dışındaki besin elementi konsantrasyonu arasında, yapılan korelasyon analizi ile çok zayıf ilişki görüldüğ̈̈ tespit edilmiştir. Yalnızca havzada kullanılan; TSP $\left(\mathrm{Na}_{3} \mathrm{PO}_{4} \cdot 12 \mathrm{H}_{2} \mathrm{O}\right)(\% 42-44$ $\left.\mathrm{P}_{2} \mathrm{O}_{5}\right)$, DAP 18.46.0 $\left(\left(\mathrm{NH}_{4}\right)_{2} \mathrm{HPO}_{4}\right)$, kompoze 20.20.0, kompoze 20.20 .0 süper, kompoze 15.15.15. süper, kompoze $13.24 .12+4 \mathrm{~S}+\mathrm{Zn}$, kompoze 12.30 .12 gübreleri ile su kaynaklarında hesaplanan ortalama ortofosfat fosforu konsantrasyonları arasındaki ilişkiye bakılmak üzere yapılan korelasyon analizlerinde; havzada kullanılan fosfor içerikli gübreler ile havzanın ortofosfat fosforu konsantrasyonu arasında orta derecede bir ilişki tespit edilmiştir $(\mathrm{r}=0,4)$.

Havzadaki yerleşim yerlerinde yaşayan halkın tarım dışındaki bir diğer gelir kaynağı da hayvanc1lıktır. Havzada 4303 büyükbaş, 30258 küçükbaş ve 2407 kümes hayvanı bulunmaktadır (TÜiK 2014).

YEGM'den alınan bilgilere göre;

1 büyükbaş hayvan 3,6 ton/yıl yaş gübre,

1 küçükbaş hayvan 0,7 ton/y1l yaş gübre,

1 kümes hayvanı 0,022 ton/yıl yaş gübre açığa çıkardığından; bu bilgilerden yola çıkılarak Pupa Çayı havzasında ortaya çıkan toplam hayvansal gübre miktarı 89624,5 ton 'dur.

\section{TARTIŞMA ve SONUÇ}

Havzada bulunan su kaynaklarında ölçülen en yüksek $\mathrm{NO}_{3}-\mathrm{N}$ değeri Ağustos ayında 6.istasyonda $(6,1 \mathrm{mg} / \mathrm{l})$ görülmüştür. Sularda nitratın asıl kaynağını azotlu gübreler, organik maddeler ve doğadaki bazı minerallerin oluşturur. Çiçek (2011) çevresel koşulların etkisiyle özellikle sel zamanlarında ve organik kirlenmenin olduğu dönemlerde nitrat değerinin önemli düzeyde arttığı, kanalizasyon sularının karışması durumunda nitrat derişiminin yükseldiği, yeşil bitkiler tarafından kullanıldığı ve bakterilerin denitrifikasyonu ile ortamdaki nitrat değerinin düşürüldüğü belirtilmektedir. En yüksek değerin Ağustos ayında 6.istasyonda görülmesinin nedeninin su kaynağına verilen 
kanalizasyon suları ve havzada yaz aylarında kullanılan amonyum nitrat, üre ve potasyum nitrat gübresi olduğu söylenebilir. Ayıca 6.istasyonda Ağustos ayında nitrat konsantrasyonun yüksekliğinden dolayı aşırı ötrofikasyon görülmüştür. Çiçek (2011)'e göre yüzey sularında nitrat azotunun $5 \mathrm{mg} / \mathrm{l}$ ' nin üzerinde olması evsel ya da tarımsal etkinliklere bağlanmaktadır. EPA (2009)'ya göre ise içme suyunda maksimum bulunması gereken nitrat azotu değerinin $10 \mathrm{mg} / \mathrm{l}$ olduğu ve içme sularındaki nitratın temel kaynaklarının kullanılan gübrelerin yüzey akışları ile sulara karışması, kanalizasyon ve erozyon olduğu bildirilmiştir.

Havzada bulunan su kaynaklarında ölçülen en yüksek $\mathrm{NH}_{4}-\mathrm{N}$ değeri Aralık ayında 3.istasyonda $(13,2 \mathrm{mg} / \mathrm{l})$ görülmüştür. En yüksek amonyum azotu miktarının Aralık ayında olmasının nedeni Eylül, Ekim, Kasım, Aralık aylarında yoğun miktarlarda kullanılan DAP 18.46.0. $\left(\left(\mathrm{NH}_{4}\right)_{2} \mathrm{HPO}_{4}\right)$ gübresi olduğu söylenebilir. Ayrıca akarsuyun etrafinda geniş tarım arazilerinin yer alması akarsuda yüksek amonyum azotu görülmesinin nedenlerinden biri olarak görülebilir.

Havzada bulunan su kaynaklarında ölçülen en yüksek $\mathrm{PO}_{4}$ - $\mathrm{P}$ değeri Aralık ayında 2.istasyonda $(27800 \mu \mathrm{g} / 1)$ görülmüştür. Fosforun temel kaynağını \%91 gibi bir oranla tarımsal alanlar oluşturmakta ayrıca evsel atıklardaki temizlik maddeleri, lağım suyu ve yiyecek maddelerinin de fosfor kaynaklarını oluşturur. Aralık ayında su akış hızının düşük olması, yerleşim yerlerinin kanalizasyon sularının 2.istasyon Ortayazı Köprüsü noktasına boşaltılmış olması, akarsuyun etrafında geniş tarım arazilerinin yer alması ve Eylül, Ekim, Kasım, Aralık aylarında DAP 18.46.0. $\left(\left(\mathrm{NH}_{4}\right)_{2} \mathrm{HPO}_{4}\right)$ gübresinin yoğun miktarlarda kullanılmış olması en yüksek ortofosfat fosforu değerinin Aralık ayında 2.istasyonda görülmesinin nedeni olarak görülebilir.

Havzada kullanılan gübrelerin su kaynaklarındaki ölçülen besin elementleri konsantrasyonlarına etkisi veri sayısının yetersiz olması ve havzadaki su kaynaklarının istikrarının kaybolmuş olması gibi etkenler de göz önünde bulundurularak değerlendirilmiştir. Earl (2009), besin elementi tahminlerinin doğruluğunu daha fazla kanıtlamak için başvurulan her bir yönteme (gübre kullanımı, hayvansal ve insan kökenli organik atık vb) daha fazla bilgi eklenmesi gerektiğini belirtmiştir.

Havzadaki su kaynaklarının besin elementleri konsantrasyonları üzerinde havzada kullanılan suni ve hayvansal gübrelerin doğrudan etkili olmadığı; yerleşim yerlerinin kanalizasyon sularının ve sulama suyu artıklarının havzadaki su kaynaklarına verilmesi, kış aylarında oluşan seller, havzada katı atık depolama yerinin bulunmaması gibi etkenlerle birlikte havzadaki besin elementlerinin kaynağı olduğu düşünülmüsstür. Tay (2005) havzada katı atık depolama tesisi için en uygun alan olarak İleydağı Köyü'nün 3 km kuzeybatısındaki Çatma Mevkii olduğunu bildirmiştir. Şener (2010) katı atık bertarafı için havzada mevcut alanın \% 96,3'nün uygun olmadığ1; \%1,6'sının orta derecede uygun; $\% 2,1$ 'inin de en uygun olduğunu belirlemiştir.

Ayrıca havzadaki su kaynaklarında hayvansal gübrelerden kaynaklanan potansiyel bir su kirliliği olduğu kanısına varılmıştır. Havzanın giriş noktasından çıkış noktasına gidildikçe besin elementleri konsantrasyonlarının arttığı görülmüştür. Ortalama besin elementleri konsantrasyonlarının en yüksek görüldügü nokta 2.istasyon (Ortayazı Köprüsü noktası) olup; nedeninin su kaynağına doğrudan boşaltılan yerleşim yerlerinin kanalizasyon suları ve su kaynağının etrafinda yer alan geniş tarım arazileri olduğu düşünülebilir. Bahar ve yaz aylarında besin elementleri konsantrasyonlarında artış görülmüş nedenleri arasında en büyük etken su kaynaklarına boşaltılan yerleşim yerlerinin kanalizasyon suları ve bununla birlikte özellikle Mart, Nisan, Mayıs aylarında yapılan 
yoğun gübreleme işlemleri olduğu söylenebilir. Smith vd. (2003)'e göre sulardaki besin elementi artışının nüfus artışına paralel olarak, yapay gübre üretimi ve kullanımı, fosil yakıt kullanımının artması ile ilgili olduğu ve bu artışın et üretimi, tarımsal ürün ihracatı verileri ile de tespit edilebileceği ortaya konmuştur.

Havzanın besin elementi yükünün bütüncül olarak belirlenebilmesi için yer altı sularının da besin elementleri konsantrasyon ve yükleri üzerinde çalışma yapılması, yüzey sularında örnekleme noktalarında daha sık aralıklarla ve çok sayıda analiz yapılması gereklidir. Yüzey suyu debilerinin kararsız olması nedeniyle elde edilen verilerdeki sapma yüksektir. Kronvang vd. (2012) nehir havzası yöneticilerinin yüzey sularında ötrofikasyonla mücadele sorununda havzadaki fosforun ana kaynakları ve fosfor bütçe hesaplaması ile ilgili çok sayıda bilginin olması, bu iki konu arasında iyi bir bağlantı kurulması gerektiğini belirtmişlerdir. Fox ve Argent (2009) ise havza modellerinin büyük ölçekli izleme ve yönetim programları için bilgilendirme ve rehberlik açısından çok değerli olduğunu belirtmişlerdir.

Senirkent ve Uluborlu yerleşim merkezleri ile bunlara bağlı olan köylerin kanalizasyon suları Pupa Çayı'na boşaltılmakta ve çayla birlikte de Eğirdir Gölü’ne karışmaktadır. Dolayısıyla Isparta il merkezinin içme suyu ihtiyacının karşılandığı Eğirdir Gölü su kalitesini olumsuz etkilemektedir. Senirkent ve Uluborlu ilçelerine ait kanalizasyon sistemlerinin bir an önce yapılması ve havzadaki bu kirliliğin kontrol altına alınması gerekmektedir. Pupa çayı havzasında hiçbir yerleşim merkezinde katı atık depolama yeri bulunmamaktadır. Havzadaki katı atıklar ve bu atıklardan sızan sular havzadaki su kaynaklarını kirletmektedir. Havza içerisine düzenli bir katı atık depolama tesis veya tesisleri kurulmalıdır.

\section{KAYNAKLAR}

Bartram, J,, \& Ballance, R. (Ed.). (1996). Water quality monitoring - A Practical Guide Tothe Design And Implementation of Freshwater Quality Studiesand Monitoring Programmes. Published on UNEP/WHO, 348p.

Canik, B, (1971). Yer altı suyu bilançosu. MTA Enstitüsü Dergisi, No:76, 181-191

Çevre ve Şehircilik Bakanlığı, 1988. Su Kirliliği Kontrolü Yönetmeliği. http://sgb.csb.gov.tr/mevzuat/dosyalar/r_20131001011242109_2b666647-5d65-4f8a-b9e638d74d61fd29.pdf (Erişim Tarihi: 13.01.2011).

Çiçek, N,L. (2011). Köprüçay Nehri (Antalya) su kalitesinin fizikokimyasal değerlere ve bentik alglere göre belirlenmesi, Süleyman Demirel Üniversitesi Fen Bilimleri Enstitüsü, Doktora Tezi, 159s, Isparta

Demer, S. (2008). Isparta ve yakın çevresi yeraltı sularının hidrojeolojik, hidrojeokimyasal ve izotop jeokimyasal incelenmesi ve içme suyu kalitesinin izlenmesi. Süleyman Demirel Üniversitesi, Doktora Tezi, 171s, Isparta

Earl, J.T., (2009). Modelling Nutrient Loads From British Catchments. University of Essex, Ph.D. Thesis, 250p, England.

EPA, (2009). National Primary Drinking Water Regulations. Erişim Tarihi: 28.09.2012. Erişim Adresi: http://water.epa.gov/drink/contaminants/upload/mcl-2.pdf .

Gıda, Tarım ve Hayvancılık İl Müdürlüğü. 2010. 2009 Yılı aylar itibariyle ve yıl sonu çiftçiye gübre satış toplamı (ton). Isparta.

Fox, D.R., \& Argent, R.M. (2009). Catchment-wideestimation of sediment-nutrientloads. 18th World IMACS / MODSIM Congress; Australia. 
Kronvang, B., Audet, J., Pedersen, A.B., Jensen, H.S., \& Larsen, S.E., (2012). Phosphorus load to surface water from bank erosion in a Danish Lowland River basin, Journal of Environmental Quality, 41, 304-313.

Liljeström, I. (2007). Nitrogen and phosphorus dynamics in the mekong basin: Nutrient balance assessment in a catchment scale. Helsinki University,M.Sc.Thesis, 130p, Finland.

Mutlutürk, M,, Karagüzel, R., Köseoğlu, M., Oran, S., Oğlakçı, M., \& Taşdelen, S., (1991). Eğirdir Gölü ve havzası kirletici faktörlerin araştırılması. Göller Bölgesi Tatlı Su Kaynaklarının Korunması ve Çevre Sorunları Sempozyumu, Isparta, Türkiye.

Seyman, F. (2005). Senirkent-Uluborlu (Isparta) havzasının hidrojeoloji incelemesi. Süleyman Demirel Üniversitesi,132s. Yüksek Lisans Tezi, Isparta.

Smith, A.R., Alexander, R.B., \& Schwarz, G.E., (2003). Natural background concentrations of nutrients in streams and rivers of the conterminous United States. Environmental Sclence\&Technology. 37 (14), 3039 - 3047.

Şener, E., Şener, Ş., \& Davraz, A. (2009). Assessment of aquifer vulnerability based on GIS and DRASTIC methods: A casestudy of the Senirkent-Uluborlu basin (Isparta, Turkey). Hydrogeology Journal, 17, 2023-2035.

Şener, Ş., Şener, E., \& Karagüzel, R. (2010). Solid waste disposal site selection with GIS and AHP methodology: A casestudy in Senirkent-Uluborlu (Isparta) basin, Turkey. Environ Monit Assess. 173, 533-554.

Tay, Ş. (2005). Senirkent-Uluborlu (Isparta) havzasının katı atık düzenli depolama yeri seçimine yönelik jeolojik - jeoteknik incelemesi. Süleyman Demirel Üniversitesi, 100s, Yüksek Lisans Tezi, Isparta.

TÜIK, (2014). İlçelere göre il/ilçe merkezi ve belde/köy nüfusu.

http://rapor.tuik.gov.tr/reports/rwservlet?adnksdb2\&ENVID=adnksdb2Env\&report=wa turkiye ilc e koy sehir.RDF\&p il $1=32 \& p$ ilce $1=1615 \& p \_$kod=2\&p_yil=2010\&p dil $=1 \&$ desformat $=$ html (Erişim Tarihi: 28.08.2015).

TÜIK, (2014a). İlçelere göre hayvancıllk istatistikleri. Erişim Tarihi: 28.08.2015. Erişim Adresi: http://tuikapp.tuik.gov.tr/hayvancilikapp/hayvancilik.zul

UNICEF, $2008 . \quad$ UnicefHandbook OfWaterQuality, http://www.unicef.org/wash/files/WQ_Handbook_final_signed_16_April_2008.pdf (Erişim Tarihi: 20.08.2011).

Yenilenebilir Enerji Genel Müdürlüğü (YEGM), (2012). Hayvan Ağırlı̆̆ı Bazında Üretilebilecek Günlük ve Yıllık Yaş Gübre Miktarları. http://www.eie.gov.tr/yenilenebilir/biyogaz.aspx (Erişim Tarihi: 23.07.2012). 